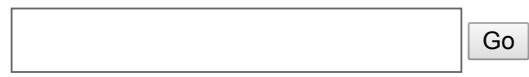

\title{
In This Section
}

Home > Food Science \& Nutrition

The Author

Andrea Madalena Maciel Guedes, PhD.

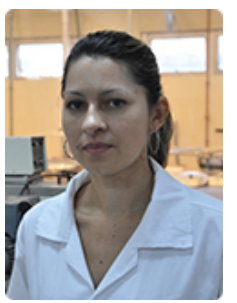

Brazilian Agricultural Research Corporation Ministry of Agriculture, Livestock and Food Supply

DOI: 10.21748/lipidlibrary.41548

\section{Pequi oil}

- Pequi oil is obtained from native species of Caryocar genus in Central and South America.

- In tropical regions it is easily fractionated at room temperature due to the content of oleic (54-60\%) and palmitic (34-40\%) acids.

- POP is among the main triacylglycerol, making it an important source of cocoa butter equivalent.

Several different denominations for the native species of Caryocar genus [C. brasiliense (from Cerrado, Amazônia, Caatinga, and Atlantic Rainforest), C. villosum (Amazonian) and C. coriaceum (found in Araripe region, Ceará, Brazil), among others] have been given, such as, pequi, pequierim, pequiá, pequirasteiro [1]. The name Pequi will be used hereinafter, unless specified.

Pequi is a yellow to orange strong flavored fruit of a perennial tree (Figure 1) adapted to low fertility soil and is regarded as important for sustainable development of the Brazilian savanna (Cerrado). It contains spiny seeds; however, a non-spiny species has also been found.

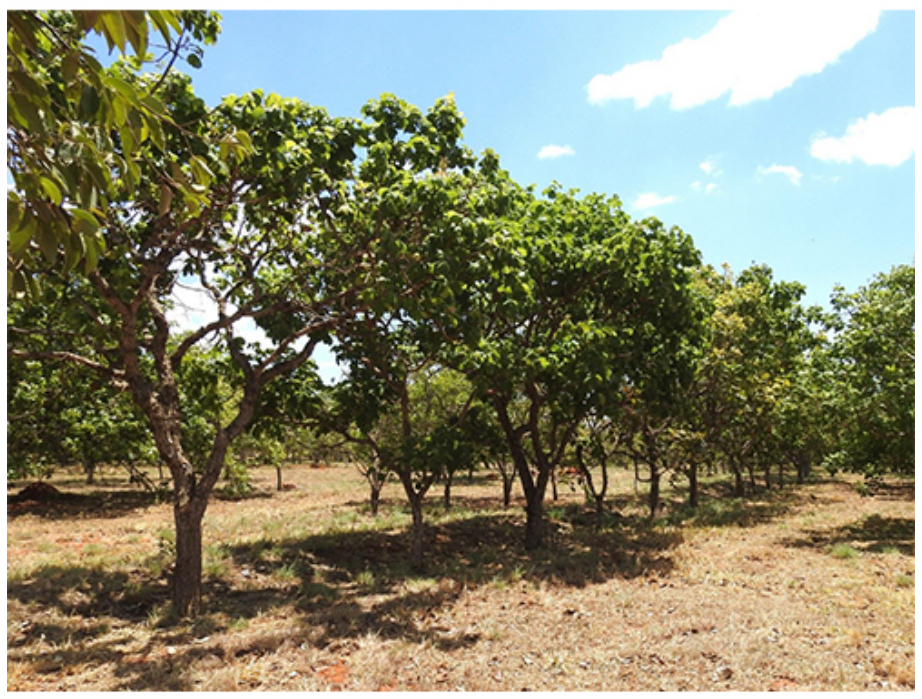

Figure 1 Pequi tree (I) cultivated at Embrapa Cerrados. Distrito Federal, Brazil. Photo: Nilton Junqueira.

Despite studies demonstrating that best management practices may enable the tree planting, Pequi fruit is still obtained by extractive activities. In order to preserve the plant, the fruit is collected after falling to the ground and it is traditionally used in local culinary as well as to obtain several marketable products, such as fruit preserves and oils both from the mesocarp (pulp) (36-66\% d.b. of fruit) and the kernel (14-48\% w.b.) $[2,3]$. 


\section{Extraction process}

Pequi oil is obtained by handcrafted methods. Basically, the manually peeled fruit is boiled in water and stirred until the oil rises the surface and is skimmed with a spoon. Alternatively, after cooling, the peeled fruit is brought down to room temperature, macerated and the oil rises to the surface as soon as cold water is added and is skimmed with a spoon. The oil is dried by heating and finally, filtered through cotton cloth [4]. This process provides a certain chemical instability, reducing its shelf life; nevertheless, it is an unrefined and cold pressed oil with preserved bioactives.

\section{Pequi oil composition}

Both pulp and kernel oils have similar fatty acid composition - i.e. 35-40\% palmitic and $54-60 \%$ oleic acid [5]; however, only the pulp oil will be discussed herein. The fatty acid composition results in a tendency to fractionate in storage [6].

\begin{tabular}{|c|c|}
\hline Fatty acid & $\%$ \\
\hline Palmitic acid & $34-40$ \\
\hline Palmitoleic & $0.7-1.4$ \\
\hline Stearic acid & $1.7-2.3$ \\
\hline Oleic acid & $54-60$ \\
\hline Linoleic acid & $1.5-2$ \\
\hline Linolenic acid & $0.3-0.7$ \\
\hline Arachidic acid & tr. -0.2 \\
\hline Eicosenoic acid & $0-0.2$ \\
\hline
\end{tabular}

Location and fruit species may affect the triacylglycerol composition and further studies showing these differences are necessary. Table 2 displays triacylglycerol composition of one of the main Pequi species, whose content of POP (and not PPO) is relatively high. New sources of POP, one of the symmetrical triacylglycerol responsible for cocoa butter functionality, have been pursued by confectionery industry as cocoa butter equivalents (CBEs), such as palm mid fraction (66\% POP). In other sources of $\mathrm{CBE}$, also frequently used in a fractionated form, such as illipe, shea stearin, and mango kernel stearin, the content of POP is approximately $7 \%, 1 \%$, and $1 \%$, respectively, with higher content of other cocoa butter typical triacylglycerols (POS, SOS) [9].

\begin{tabular}{|cc|}
\hline Table 2. Triacylglycerol composition of Pequi oil (\%) & from C. brasiliense [5,7] \\
Triacylglycerol & $\%$ \\
OOL & $1.1-3.8$ \\
POL & $2.2-2.7$ \\
PPL & $0-0.6$ \\
OOO & $5.4-10.5$ \\
POO & $22.9-38.7$ \\
POP & $27.6-33.7$ \\
PPP & $0-0.3$ \\
SOO & $2.1-9.1$ \\
POS & $3.2-18.2$ \\
PPS & $0-0.3$ \\
SOS & $0-8.7$ \\
\hline
\end{tabular}

Concerning bioactive compounds, around $400 \mathrm{mg} / \mathrm{kg}$ of carotenoid in Pequi oil (I) have been reported [5].

\section{Recent studies and potential technological applications}

Pequi contains a balanced proportion of palmitic and oleic acid, leading to phase separation at room temperature in tropical countries, i.e., countries of origin. Furthermore, the fatty acid and the triacylglycerol composition result in a lack of functionality regarding its industrial application [5]. However, chemical and enzymatic changes in triacylglycerols have been shown both for the purpose of improving functionality indirect application or providing structure [5], as well as attempting to obtain a cocoa butter-like fat [7].

Pequi oil triacylglycerol composition may vary according to the origin or species of I and consequently offers a set of different products. Due to the high content of POP in Pequi (I) as well as trioleic and dioleic acid triacylglycerols [5], this species presents high added value for both chocolate and high oleic oils industries.

\section{Literature}

1. Caryocaraceae in Flora do Brasil 2020 em construção. Jardim Botânico do Rio de Janeiro.Disponível em: <http://reflora.jbrj.gov.br/reflora/floradobrasil/FB16721>. Acesso em: 03 Out. 2017

2. Faria-Machado AF, Tres A, van Ruth SM, Antoniassi R, Junqueira NTV, Lopes PSN, Bizzo HR. 2015. Discrimination of pulp oil and kernel oil from pequi (Caryocar brasiliense) by fatty acid methyl esters fingerprinting, using GC-FID and multivariate analysis. J Agric Food Chem 63:10064-10069. 
3. Rogério JB, Duarte ID, Santos MCS, Antoniassi R, Faria-Machado AF, Bizzo HR, Junqueira NTC, Duboc E. 2012.Variação da composição dos ácidos graxos dos óleos de polpa e amêndoa de pequi. In: congresso da rede brasileira de tecnologia de biodiesel, 5.; Congresso brasileiro de plantas oleaginosas, óleos, gorduras e biodiesel, 8. Salvador. Lavras: UFLA 1:275-276.

4. Araujo FD. 1995. A review of Caryocar brasiliense (Caryocaraceae) - an economically valuable species of the central Brazilian Cerrado. Econ Bot 49:40-48.

5. Guedes AMM, Antoniassi R, Galdeano MC, Grimaldi R, Carvalho MG, Wilhelm AE, Marangoni AG. 2017. Length-scale specific crystalline structural changes induced by molecular randomization of pequi oil. J Oleo Sci 66:469-478.

6. Guedes AMM, Antoniassi R, Faria-Machado AF. 2017. Pequi: a Brazilian fruit with potential uses for the fat industry. OCL, 2017. DOI: https://doi.org/10.1051/ocl/2017040

7. Facioli NL, Gonçalves LAG.1998. Modificação por via enzimática da composição triglicerídica do óleo de piqui (Caryocar brasiliense Camb). Quím Nova 21:16-19.

8. Pessoa AS, Podestá R, Block JM, Franceschi E, Dariva C, Lanza M. 2015. Extraction of pequi (Caryocar coriaceum) pulp oil using subcritical propane: determination of process yield and fatty acid profile. J Superc Fluids 101: 95-103.

9. Gunstone FD. 2011. Vegetable oils in food technology composition, properties, and uses, 2nd ed. West Sussex: Willey-Blackwell, p. 291-343.

\author{
Editorial Board | \\ Privacy Policy | \\ Contact Us | \\ AOCS Website |
}

2710 S. Boulder, Urbana, IL 61802-6996 USA

Phone: +1 217-359-2344 | Fax: +1 217-351-8091

Copyright (C) 2017 The American Oil Chemists' Society | Powered by the AOCS Foundation 